\title{
Козырева Е.А. \\ Ближние усадьбы высшей знати, как феномен историко-градостроительной жизни Санкт-Петербурга, на примере усадьбы Державина
}

Санкт-Петербургский государственный архитектурно-строительный

университет

doi: $10.18411 / s p c-28-10-2017-01$

(Россия, Санкт-Петербург)

idsp: 000001:spc-28-10-2017-01

\section{Аннотация}

В работе рассматривается феномен ближних усадеб высшей знати, как часть истории и градоформирующий аспект в формировании города Санкт-Петербурга и его окрестностей. Более подробно рассматривается история и этапы формирования, строительства и реконструкции усадьбы Державина, как одного из примеров ближних усадеб высшей знати. Данный объект был создан талантом выдающихся зодчих, но уже в ХІХвеке начались работы по приспособлению его территории и здания для развивающейся территории города. Проблемы сохранения и приспособления для современного использования в настоящее время такого типа объектов остро стоят перед архитектурным сообществом.

Ключевые слова: усадьбы высшей знати, усадьба Державина, проблемы сохранения объекта.

В Санкт-Петербурге и вокруг Санкт-Петербурга до 1917Г можно отметить наличие усадеб, которые по своему содержанию и амбициозности, могут в чем-то поспорить с Императорскими загородными дворцово-парковыми комплексами. Но в тоже время имеют характерные отличительные особенности, по которым их можно отделить как от Императорских дворцовых загородных комплексах, так и от помещичьих усадеб. Такой особый тип объектов можно обозначить как «ближние усадьбы высшей знати». Это не Императорские пригородные резиденции, и не дворянские загородные дачи. Усадьбы (точнее - дворцово-парковые комплексы) высшей знати традиционно развивались как особый тип объектов на прилегающей к столичному городу территории. В настоящее время многие из них находятся в границах современной городской черты [8, с. 17].

По размерам (как зданий, так и парков) они существенно отличаются от рядовых дворянских усадеб. Здания для ближних усадеб высшей знати, как и для дворцовых загородных комплексов, строили известные придворные архитекторы, как бы сейчас сказали «модные», в модных в то время стилях.

К высшей знати, в контексте данного исследования, отнесены представители дворянства, приближенные ко двору, но не входящие в Императорскую семью, имеющие высокое социальное значение в структуре общества (не ниже 4 класса по табели о рангах).

В Санкт-Петербурге в разное время (века и десятилетия) существовали подобные усадьбы создавали вокруг города некий композиционный каркас в ряде литературных источников называемый поясом (зеленым кольцом). Постепенно, с увеличением границ города часть этих усадеб входила в состав города, они реконструировались, изменялись, исчезали. До нашего времени дошла только часть таких грандиозных усадеб, которые можно выделить в отдельный «слой» и рассматривать как отдельный феномен. 
Эти усадьбы создавали великолепные миры вокруг столичного города и были амбизиозными центрами притяжения, зачастую предрешая судьбу владельцев (Каменный остров - Бестужев-Рюмин). В некоторых случаях, когда владелец разорялся, такие усадьбы выкупались в казну города, становясь Императорскими резиденциями (Елагин остров, Таврический дворец и т.п.) иногда передавались лечебным организациям (Дача К.Е. Сиверса, Новознаменка и т.п.).

Одним из примеров таких «утраченных» усадьб является резиденция Державина на Фонтанке.

По берегам реки Фонтанки уже С 1710-х гг. раздавались земли для загородных дач царским вельможам, а 1724 г. Главная полицмейстерская канцелярия, которая велела отводом хмельных участков, определила их размеры (50 саж. в ширину и 100200 саж. в длину). Согласно указу Петра I от 11 февраля 1724г. каждый владелец должен был застроить свой участок в течение 4-х лет «по образцовым печатным о загородных дворах листам» и оставшуюся часть пилить огородом. Все это обусловило характер дальнейшей планировки района. На размер участков вдоль Фонтанки влияли две улицы Загородная и Садовая, проложенные вдоль ее берегов позади дворов. [4, с. 62]

В 1730-х тт. территория, на которой впоследствии располагалась усадьбе Державина, еще не была застроена. Небольшая загородная усадьба была устроена первым владельцем этой земли А.В. Олсуфьевым. [6, с. 254]

В январе 1788 г. дачу Олсуфьева приобрела жена сенатора и члена Российской Академии наук И.С. Захарова - М.П. Захарова.

В 1791 г. у Захаровой дом купили Державины. Официально владелицей усадьбы стала первая жена поэта Е.Я. Державина. Строителем дома являлся архитектор Конторы строений домов и садов ее величества Г.П. Пильников. После перехода дома к Державину, он остался при строениях и продолжал работы. [5, с. 94]

В 1741-1792 гг. к главному дому пристроили два равных по размерам прямоугольных флигеля. С домом они соединялись полуциркульными переходами в виде галерей и вначале были меньшими о протяженности, так что не доходили до набережной Фонтанки. [7, с. 399]

В 1813 г, не задолго до своей смерти Г.Р. Державин завещал дом на Фонтанке своей второй жене М Д. Дьяковой. После кончины поэта в 1816 г. значительных работ и усадьбе не проводилось. Часть участка, ближе к 1-й роте Измайловского полка, с 1825 г. арендовали под огород крестьяне Титов и Сорогин, с 1826 г. в наем был сдан деревянный дом.

В 1846 г. участок с домом Державина приобрела Римско-католическая духовная коллегия. Купчая была совершена 4 июня 1846 г. Дом для коллегии оказался не достаточно вместительным и началась его перестройка. [6, с. 254]

В доме расположилась коллегия, там же находились квартиры служащих коллегии, митрополии, каплица (часовня), канцелярия, архив и касса.

Одновременно с перестройкой дома для коллегии возобновились работы по саду. Проект был составлен в 1846г А.Гумлером. По нему он сохранял прежнюю планировку сада, при этом пруды соединил каналами, через которые были перекинуты мостики. В период с осени 1846 по весну 1847 г. в саду высадили деревья, устроили куртины и дорожки.

Часть участка в 1870г. была выделена под постройку здания для учреждений Могилевской епархии. 
К 1917 г. усадьба Державина сильно изменила свой первоначальный вид: утрачено большинство интерьеров, внесены существенные исправления в оформление фасадов. После революции здание было превращено в обычный жилой дом. [4, с. 64]

В октябре 1924 г. дом перешел из ведения правления жилтоварищества и распоряжение коммунального отдела. Здание выглядело крайне запушенным. В 1935 г. проходил неотложный ремонт кровли.

В 1936 г. помещения бывшего архива коллегии в западном крыле главного корпуса приспособили, под жилье. До этого времени их использовала мастерская технического комбината им. Фрунзе, вырабатывавшая гуталин.

21 августа 1919 г. Отдел по охране, учету и регистрации памятников искусства и старину принял здание под государственную охрану.

Сад - нач. 1930-х, частичная перепланировка, 1946 сад перепланирован, арх. А.Т. Тризна; 2-я пол. 20в.- частичные перепланировки.

В середине 1990-х гг. дом передан Всероссийскому музею А.С. Пушкина для устройства в нем филиала, посвященного жизни и творчеству Г.Р. Державина и русской словесности его времени.

Центральный корпус (музейный)- 2001-2003, реставрирован. Институт «Ленпроектреставрация», арх. А.Г. Белов, Л.А. Одинцова.

Таких усадеб, как Дворцово-паркового ансамбля Знаменской дачи, в разное время было не более 50, некоторые из них частично сохранились и дошли до наших дней, некоторые остались в истории и воспоминаниях современников тех лет. Наше время требуется сохранение этого исторически сложившегося феномена «ближних усадеб высшей знати» не только как градостроительных объектов, но и как фундаментальных следов развития культуры и дореволюционной жизни города. Столичный Санкт-Петербург не мог оставаться только в границах императорских резиденций, не мог существовать без этого великолепного ожерелья пригородных усадеб высшей знати.

$$
* * *
$$

1. Антонов, В. В. Святыни Санкт-Петербурга / В. В. Антонов, А. В. Кобак. - СПб. : Издательство Чернышева, 1996. - 490 с.

2. Богуславский, М. М. Международная охрана культурных ценностей / М. М. Богуславский. - М. : Международные отношения, 1979. - 192 с.

3. Канн, П. Я. Прогулки по Петербургу / П. Я. Канн. - СПб. : Палитра, 1994. - 320 с.

4. Колотов, М. Г. Дом Державиных и декоративные рельефы в его парадных интерьерах / М. Г. Колотов, Е. Ф. Ходаковский. // История Петербурга. - 2004. - 3 (19). - С. 60-69.

5. Пунин, А. Л. Архитектура Петербурга середины и второй пол. ХІХ века. Том 2. Петербург 1860 1890-х годов в контексте градостроительства пореформенной России / А. Л. Пунин. - СПб. : Крига, 2014. $-600 \mathrm{c}$.

6. Пыляев, М. И. Старый Петербург. Рассказы из былой жизни столицы / М. И. Пыляев. - М. : ДиректМедиа, 2007. -817 с.

7. Генрих, фонРеймерс. Санкт-Петербург в конце своего первого столетия / фонРеймерс. Генрих. СПб. : Росток, 2007. - $534 \mathrm{c}$.

8. Семенцов, С. В. Развитие регулярной Санкт-Петербургской агломерации после Петра Великого и проблемы ее сохранения как Объекта Всемирного наследия / С. В. Семенцов. // Вестник гражданских инженеров. - 2014. - 4. - С. 16-24.

9. Федеральный закон от 25.06.2002 № 73-Ф3 «Об объектах культурного наследия (памятниках истории и культуры) народов Российской Федерации» // «Парламентская газета», №120-121, 29.06.2002 